\title{
Relationships between Pre-service Teachers' Social Media Usage in Informal Settings and Technological Pedagogical Content Knowledge
}

\author{
Wilfred W. F. Lau ${ }^{1 *}$ \\ ${ }^{1}$ Department of Curriculum and Instruction, The Chinese University of Hong Kong, Hong Kong SAR, CHINA
}

Received 28 March 2018 • Revised 13 June 2018 - Accepted 14 July 2018

\begin{abstract}
Social media are increasingly adopted in university administration, teaching, and learning. For pre-service teachers, although there is growing evidence suggesting the effectiveness of educational technology courses in enhancing their technological pedagogical content knowledge (TPACK), relatively little is known about whether and how this knowledge is associated with social media usage (SMU) in informal settings. In this study, the relationships between SMU in informal settings and TPACK among pre-service teachers were investigated. Based on the survey data of a sample of 212 pre-service teachers in Hong Kong, media sharing was found to be a significant positive predictor of technology knowledge and knowledge of teaching with technology, whereas Internet searching and video gaming were not predictive of any component of TPACK. The findings of the study were interpreted in the light of the educational affordances of social media technologies, and their implications for researchers and teacher educators were discussed.
\end{abstract}

Keywords: pre-service teachers, social media usage, informal settings, technological pedagogical content knowledge, teacher education

\section{INTRODUCTION}

Currently, many students grow up in digital environments surrounded by a host of technological artefacts. The ubiquity of technology provides students with numerous opportunities to explore the world in both formal and informal contexts. In particular, the emergence of Web 2.0 applications allows students to create, share, collaborate, and communicate ideas instantly online with almost no need for technical expertise. Although social media usage (SMU) has become increasingly prevalent in education, its relevant benefits have yet to be evaluated. In general, SMU refers to "the multiplicity of activities individuals may participate in online" (Smith \& Gallicano, 2015, p. 83). Junco (2012) showed that in a large sample of college students, time spent using Facebook significantly negatively predicted overall grade point average. However, when examined in greater detail, the results indicated that using Facebook for collecting and sharing information positively predicted overall grade point average, and using Facebook for socialising negatively predicted the same outcome variable.

Technology integration in teaching practice has become increasingly common in schools. The successful implementation of this complicated process hinges on multiple factors at different levels in a school system. Teachers play a vital role in introducing technology-based instruction in a classroom setting, and must be prepared to use technology in teaching. Within the teacher knowledge domain, studies have indicated the importance of developing technological pedagogical content knowledge (TPACK) (Mishra \& Koehler, 2006; Oskay, 2017; Thompson \& Mishra, 2007) among teachers to ensure they can teach effectively with technology. TPACK represents the complex interactions among content knowledge (CK), pedagogy knowledge (PK), and technology knowledge (TK). Whereas in-service teachers may continue to enhance and practise TPACK through professional development programmes, pre-service teachers mainly develop TPACK through formal study in university, which includes "(a) stand-alone educational technology course, (b) instructional strategies embedded within an educational technology

(C) 2018 by the authors; licensee Modestum Ltd., UK. This article is an open access article distributed under the terms and conditions of the Creative Commons Attribution License (http://creativecommons.org/licenses/by/4.0/). \wwflau@cuhk.edu.hk wilfredlau@graduate.hku.hkwflau.geo@yahoo.com (`Correspondence) 


\section{Contribution of this paper to the literature}

- This study is among the first empirical investigation to examine the relationships between SMU in informal settings and TPACK among pre-service teachers.

- Results showed that media sharing was found to be a significant positive predictor of technology knowledge and knowledge of teaching with technology, whereas Internet searching and video gaming were not predictive of any component of TPACK.

- The findings of the study provide new insights and advance knowledge on how to prepare pre-service teachers to integrate technology in their professional practices through the effective and novel use of social media technologies in universities.

course or content-specific method courses, and (c) instructional strategies implemented in the context of entire teacher education programs" (Mouza, 2016, p. 175).

As far as using social media in formal education is concerned, Kumar and Leeman (2013) designed an educational technology course for student teachers of social studies that focused on SMU in the teaching and learning process and in online community building with experts. Their findings indicated that student teachers gained confidence in and knowledge of using new technology and social media in K-12 classrooms. Tur and Marin (2015) introduced Twitter into a debate activity for student teachers and assessed its impact on how they learned and understood the debate topic. The student teachers expressed positive perceptions of SMU in education and were willing to use social media in this context in the future. They also responded positively to the educational possibilities of Twitter and social networks. Lemon (2016) integrated use of the social media platform Twitter into an accredited teacher education core course to support the professional development of pre-service teachers. The social media tool helped pre-service teachers develop their online identities and bolster peer support, reflective practice, and professional networking.

Whereas growing evidence suggests the effectiveness of educational technology courses in enhancing TPACK for pre-service teachers, relatively little is known as to whether and how SMU in informal settings - such as outside of the classroom environment (Bahrani, Sim, \& Nekoueizadeh, 2014)-may influence pre-service teachers' development of TPACK. SMU in informal settings among pre-service teachers is valuable because of its potential to contribute to informal learning, which will be delineated in more detail later in this paper. Therefore, the main research question of this study was: 'What are the relationships between SMU in informal settings and TPACK among pre-service teachers?'

\section{SIGNIFICANCE OF THE STUDY}

With the growing popularity of SMU among university students, more research work is required to explicate the relationships between SMU and TPACK acquisition among pre-service teachers. This study aimed to understand whether and how SMU in informal settings is associated with TPACK for pre-service teachers. On the one hand, research in this area helps broaden understanding of how TPACK is related to SMU in informal contexts - for example, how SMU in an out-of-classroom setting is interwoven with the components of TPACK to various extents. On the other hand, research in this area provides important information to teacher educators with regard to the design of educational technology courses. Traditionally, these courses were planned with reference to student prerequisites only, and generally assumed that students lacked TPACK or did not consider students' prior TPACK (Mouza \& Karchmer-Klein, 2015). If the findings of this study indicate significant relationships between SMU in informal settings and TPACK for pre-service teachers, course instructors may incorporate these findings into the design of teaching materials and customise the materials according to student needs. Furthermore, teacher educators can improve their ability to identify and realise the learning benefits of social media as digital environments that are linked to TPACK (Carpenter \& Krutka, 2015), helping to inform the design of personalised learning environments (Dabbagh \& Kitsantas, 2012).

\section{THEORETICAL FRAMEWORK OF THE STUDY}

McLoughlin and Lee (2007) coined the term Pedagogy 2.0 to depict "how individuals link with communities and networks in the process of knowledge sharing, construction and understanding" (p. 668) supported by social software tools. Three key pillars underlie Pedagogy 2.0, namely personalisation, participation, and productivity (McLoughlin \& Lee, 2008). Modern technologies provide learners with easy access to an array of resources for their individual learning needs (personalisation). Learners are expected to be actively involved in idea sharing, concept inquiry, and problem solving through interactions with their peers, teachers, and subject experts in various community settings (participation). They are encouraged to construct knowledge in a social process instead of being passive recipients of information from their instructors (productivity). 
This pedagogical approach places great emphasis on the interdependence of ideas, individuals, communities, and information networks, and provides a theoretical framework for the present study. As individuals share and exchange ideas or digital artefacts through social media communities and networks in informal settings, this practice promotes collaboration, creativity, and connections among them that ultimately results in the generation of joint knowledge. For example, social media enable the integration of online information from a variety of sources that is generated, disseminated, and used by teachers for their design of the educational process, including learning objectives, teaching strategies, classroom activities, and assessment methods (Mâță, 2014). This leads to the development of TPACK, which generally refers to knowledge teachers needed to utilise technology in their teaching (Mishra \& Koehler, 2006). From this perspective, it is hypothesised that significant relationships exist between pre-service teachers' SMU in informal settings and their TPACK.

\section{SOCIAL MEDIA AND INFORMAL LEARNING}

In the U.S., a study based on a proportional national sample of 456 four-year accredited institutions found that all reported the use of some forms of social media; Facebook (used by 98\%) and Twitter (used by $84 \%$ ) were the most prominent (Barnes \& Lescault, 2011). Social media are increasingly adopted in university administration, teaching, and learning. Social media can be understood as "a group of Internet-based applications that build on the ideological and technological foundations of Web 2.0, and that allow the creation and exchange of user-generated content" (Kaplan \& Haenlein, 2010, p. 61). Specifically, for university students, Hu and Zhang (2016) found four conceptual dimensions of SMU, which include relationship developing, information sharing, self-presenting, and entertaining.

Social media technologies come in a variety of forms, including magazines, Internet forums, blogs, microblogs, wikis, social networks, podcasts, photographs or pictures, videos, ratings, and social bookmarking sites (Baruah, 2012). In the higher education sector, social media make possible the blending of informal learning into formal education. According to a report compiled by Johnson, Adams, Becker, Estrada, and Freeman (2015), students considered information delivered through university social media to be more trustworthy than the same content available on university websites. Students increasingly depend on their Facebook and Twitter newsfeeds for updates on major global events, and use these platforms for sharing and collecting feedback on their work.

Informal learning occurs in learning situations that are initiated by the learners (Jahnke, 2012). It typically involves a cycle of four stages: (1) gaining concrete experiences in a situation; (2) observing and reflecting on experiences; (3) formulating abstract concepts through analysis and making generalisations; and (4) testing hypotheses in future scenarios, leading to new experiences (Kolb, 1984). As informal learning is facilitated by the environment and its supporting structures, social media tools are ideal platforms. In particular, Greenhow and Lewin (2016) argued that although the boundary between formal and informal learning is becoming increasingly blurred, social media provide a possible approach to bridge the two learning opportunities through participatory digital cultures (Jenkins, Purushotma, Weigel, Clinton, \& Robinson, 2009) where the distinction between "selfdirected, intentional learning and spontaneous, incidental and experiential learning" (p. 8) becomes less clear.

Dabbagh and Kitsantas (2012) developed a three-level pedagogical framework to integrate formal and informal learning through social media and support students' self-regulated learning in higher education. The first level of the framework, called personal information management, requires instructors to encourage students to create a personalised learning environment using social media and engage them in self-regulated learning. The second level, called social interaction and collaboration, requires instructors to encourage students to use social media in basic sharing and collaborative activities. The third level, called information aggregation and management, expects instructors to encourage students to synthesise and aggregate information from the first two levels using social media and reflect on their overall learning experiences. Charlesworth and Sarrasin (2014) found evidence to support the application of the framework in their analysis of social media activities engaged in by university educators and students.

\section{TECHNOLOGY INTEGRATION AND TECHNOLOGICAL PEDAGOGICAL CONTENT KNOWLEDGE}

Technology integration has been a critical research topic in teacher education for over 30 years (Ertmer, Ottenbreit-Leftwich, Sadik, Sendurur, \& Sendurur, 2012). Studies have identified a number of factors influencing the effective integration of technology in classroom practice. Ertmer (1999) found two types of barriers to the adoption of technology in the classroom: first-order barriers that were extrinsic to teachers (resources, training, and support) and second-order barriers that were intrinsic to teachers (teacher confidence, beliefs about teaching and learning, and value of technology in education). Tsai and Chai (2012) suggested that the existence of third-order barriers could hinder technology integration even after the first- and second-order barriers are removed. These third-order barriers concern a lack of design thinking skills, which are crucial for teachers to "re-organise or create 
learning materials and activities, adapting to the instructional needs for different contexts or varying groups of learners" (p. 1058).

Ongoing efforts have been made to help in-service and pre-service teachers overcome barriers to technology integration. For in-service teachers, professional development programmes are widely recognised as an effective strategy (Lau \& Yuen, 2013b). Lau and Yuen (2013a) showed the general positive effects of educational technology training on teacher perceptions of technology integration. After five 3-hour professional training sessions on the use of technology in the teaching and learning of mathematics, in-service teachers reported higher perceived efficacy in using technology in mathematics education and believed that using technology was beneficial to mathematics instruction. Although contemporary pre-service teachers have grown up in environments with various digital technologies, they still lack the ability and skill to use technology in classroom contexts. They struggle to integrate pedagogy, content, and technology into their teaching, and lack support and role models (Nadelson et al., 2013). Thus, numerous studies have been conducted to address this problem through the development of TPACK among pre-service teachers (Alayyar, Fisser, \& Voogt, 2012; Bilici, Guzey, \& Yamak, 2016; Koh \& Divaharan, 2011; Tokmak, 2015).

Shulman (1987) asserted that the most vital and distinctive category of knowledge for teaching is pedagogical content knowledge (PCK), namely "the blending of content and pedagogy into an understanding of how particular topics, problems, or issues are organised, represented, and adapted to the diverse interests and abilities of learners, and presented for instruction" (p. 8). Teachers should design their pedagogies based on their knowledge of curriculum, assessment, instructional strategies, and student understanding of subject content. Mishra and Koehler (2006) added a technology component to PCK, and the interactions among the pedagogy, content, and technology components created new knowledge domains, including technological content knowledge (TCK), technological pedagogical knowledge (TPK), and technological pedagogical content knowledge (TPCK). Taken together, the TPCK model has seven knowledge components, namely PK, CK, TK, PCK, TCK, TPK, and, finally, TPCK. Interested readers may refer to the seminal paper by Mishra and Koehler (2006) for the detailed definitions of these components. The TPCK model represents a framework that "allows us to make sense of the complex web of relationships that exist when teachers attempt to apply technology to the teaching of subject matter" (Mishra \& Koehler, 2006, p. 1044). TPCK, later renamed TPACK (Thompson \& Mishra, 2007), calls for teachers to increase not only their knowledge of pedagogy, content, and technology in their subject areas but also their understanding of the complex interplay between these components to ensure the effective integration of technology into classroom practice.

Studies have demonstrated the positive effects of educational technology courses on the development of TPACK among pre-service teachers. Horzum (2013) contended that teacher education programmes should focus on both teaching pre-service teachers to use technology and developing their TPACK. The author found that the TK, TCK, TPK, and TPACK of pre-service teachers significantly increased after they completed a course on developing their TPACK and technology usage skills. In Chai, Koh, and Tsai's (2010) study, teachers made significant gains in TK, PK, CK, and TPACK after completing an information and communication technology (ICT) course that was designed with reference to the TPACK framework. This provided evidence that the course helped teachers develop their knowledge in their respective domains. In another study by Chai, Koh, Ho, and Tsai (2012), pre-service teachers reported significant increases in Web 2.0-related TK, PK, CK, and TPACK after completing an ICT course designed to integrate Web 2.0 tools into lessons. Longitudinally, Hofer and Grandgenett (2012) also found significant development of pre-service teacher TPK and TPACK when studying a master's degree programme that contained an educational technology course and teaching method courses that addressed technology use to varying degrees.

However, as Gibson (2008) argued, TPACK can also be characterised as a learning environment or educative experience, and it is thus legitimate to conceive learning in this characterisation as having varying attributes of formality and informality (Greenhow \& Lewin, 2016). This notion of TPACK beyond the knowledge perspective is especially germane to pre-service teachers because pedagogical practices requiring formal and informal learning are common and necessary. Furthermore, pre-service teachers have increasingly brought informal practices, including those learned through social media, into formal educational contexts (Stoicheva, Mavrodieva, \& Tsvetkova, 2012). These viewpoints show the importance of investigating SMU in informal settings in terms of TPACK for pre-service teachers.

\section{METHOD}

\section{Participants and Procedure}

A total of 212 pre-service teachers studying in the Faculty of Education of a university in Hong Kong participated in this study on a voluntary basis. Among them, 27 provided no information on their gender, age, 
major, and year of study. The sample consisted of 57 men and 128 women with ages ranging from 18 to 25 years $($ mean $=20$; sd $=1.769)$. Their main areas of study were Chinese Education $(n=46)$, English Education $(n=56)$, Mathematics Education $(\mathrm{n}=36)$, Liberal Studies Education $(\mathrm{n}=40)$, and Physical and Health Education $(\mathrm{n}=7)$. There were 71 first-year, 27 second-year, 21 third-year, 64 fourth-year, and 2 fifth-year students. In terms of ITrelated learning experiences and proficiency, $77 \%$ and $80 \%$ of the pre-service teachers had completed computer or IT courses in secondary school and university, respectively. They possessed 12-14 years of experience in using computers or IT and perceived their IT proficiency to be good.

The research was conducted in 2016. Ethical approval was obtained from the Survey and Behavioural Research Ethics Committee of the university where the author works. All participants provided informed consent prior to data collection. Data were collected from the participants anonymously through an online survey. They were first invited to respond to items that measured their SMU in informal settings and TPACK. Then they proceeded to provide demographic information such as gender, age, major, year of study, computer or IT courses taken in secondary school or university, experiences in using computers or IT, and IT proficiency.

\section{Measures}

Gender was coded as 1 for male and 2 for female. The participants reported their major and year of study in a multiple choice format and their age, computer or IT courses taken in secondary school, and computer or IT courses taken in university in an open response format. Experiences in using computers or IT were measured on a sevenpoint scale: less than 3 years (1), 3-5 years (2), 6-8 years (3), 9-11 years (4), 12-14 years (5), 15-17 years (6), and more than 17 years (7). IT proficiency was recorded on a five-point scale: beginner (1), fair (2), good (3), very good (4), and expert (5).

The Media Usage Subscale of the Media and Technology Usage and Attitudes Scale (Rosen, Whaling, Carrier, Cheever, \& Rokkum, 2013) was adapted to understand the SMU patterns of students in informal settings (i.e. outof-classroom setting). It was used with a large sample of U.S. adults, the majority of whom were college degree holders, and also university students in Hong Kong (Lau, 2017). For the purpose of the study, 12 items that measured media sharing (MS) (five items), Internet searching (IS) (four items), and video gaming (VG) (three items) were adapted, which were conceptually related to the information sharing and entertaining dimensions of SMU found among university students (Hu \& Zhang, 2016). These items were selected to measure the SMU of pre-service teachers in informal settings because they represented online activities that are common among education students in universities (Kiedrowski, Mahrholz, Griesbaum, \& Rittberger, 2015; Korkmaz \& Avci, 2016). Students were asked to report how often they engaged in the described activities when using social media in informal settings. Items were scored on a 10-point frequency scale: never (1), once a month (2), several times a month (3), once a week (4), several times a week (5), once a day (6), several times a day (7), once an hour (8), several times an hour (9), and all the time (10).

The adapted TPACK instrument described by Jordan (2013) was used to elicit the respective knowledge components from pre-service teachers in the study. This instrument was adapted from the one developed and validated by Schmidt et al. (2009) and was used with novice teachers in Australia. The adaptation involved the removal of the focus on the four content areas (literacy, mathematics, science, and social studies) and the replacement of relevant items with context-based items. It comprised 25 items scored on a five-point Likert scale (1: strongly disagree to 5: strongly agree). According to Jordan (2013), there were four items in TK, two items in CK, seven items in PK, one item in PCK, one item in TCK, nine items in TPK, and one item in TPACK.

\section{Data Analysis}

A path analysis model was used to examine the relationships between SMU in informal settings and TPACK among students in the study. It was constructed based on the variables derived from the respective items. This analysis extends the limitations of multiple regression and allows for the examination of situations with several final dependent variables. The main objective of path analysis is to estimate the magnitude and significance of hypothesised relationships among sets of variables illustrated in path diagrams. Before the analysis, the data were checked for the absence of outliers and normality.

\section{RESULTS}

Exploratory factor analysis using the principal axis factoring method with promax rotation was performed on the 12 items that measured MS, IS, and VG. This procedure was carried out to determine the factor structure of the SMU items and verify the factor structures found in another studies involving different samples (Izquierdo, Olea, \& Abad, 2014). The Bartlett's test of sphericity was significant $(\mathrm{p}<.001)$ and the Kaiser-Meyer-Olkin $(\mathrm{KMO})$ measure of sampling adequacy was .799, which showed the appropriateness of the data for factor analysis. Based 
Table 1. Results of exploratory factor analysis on the SMU items adapted from the Media and Technology Usage and Attitudes Scale

\begin{tabular}{ll}
\hline & Factor Loadings \\
\hline Media Sharing (MS, $\alpha=\mathbf{7 8 6})$ & .313 \\
\hline MS2. Watch TV shows, movies, etc. on a computer & .335 \\
\hline MS3. Watch video clips on a computer & .899 \\
\hline MS4. Download media files from other people on a computer & .859 \\
\hline MS5. Share your own media files on a computer & .430 \\
\hline Internet Searching (IS, $\boldsymbol{\alpha}=\mathbf{. 7 9 7})$ & .889 \\
\hline IS1. Search the Internet for news on any device & .762 \\
\hline IS2. Search the Internet for information on any device & .779 \\
\hline IS3. Search the Internet for videos on any device & .689 \\
\hline IS4. Search the Internet for images or photos on any device & .765 \\
\hline Video Gaming (VG, $\alpha=.813)$ & .873 \\
\hline VG1. Play games on a computer, video game console or smartphone by yourself \\
\hline VG2. Play games on a computer, video game console or smartphone with other people in the same room \\
\hline VG3. Play games on a computer, video game console or smartphone with other people online
\end{tabular}

on the Kaiser criterion (eigenvalue greater than one) and scree test, three factors (MS, IS, and VG) that explained $62.823 \%$ of the total variance of the original items were extracted. One item MS1 'Watch TV shows, movies, etc. on a TV' was eliminated due to its low loadings on all the factors. The high factor loadings found on IS and VG, as compared to those of MS, indicated that the dimensions of the factors IS and VG were better explained by their manifest variables (Yong \& Pearce, 2013). MS, IS, and VG were loaded with four, four, and three items, respectively, consistent with Rosen et al.'s (2013) study. The alpha reliability of the factors ranged from .786 to .813 (see Table 1).

In a similar vein, to uncover the factor structure of the TPACK items, exploratory factor analysis using the principal axis factoring method with promax rotation was conducted on the 25 items that assessed the seven knowledge components TK, CK, PK, PCK, TCK, TPK, and TPACK. Again, the Bartlett's test of sphericity was significant $(\mathrm{p}<.001)$ and the KMO measure of sampling adequacy was .881 , which showed that the data were suitable for factor analysis. Contrary to our expectation, the results based on the Kaiser criterion and scree test yielded four factors that explained $60.087 \%$ of the total variance of the original items. It is evident from Table 2 that apart from the items of TK and CK that loaded on the first two factors as expected, the items of PK and PCK loaded on the third factor and those of TCK, TPK, and TPACK loaded on the fourth factor. Koh, Chai, and Tsai (2010) reported similar findings in their study of Singaporean pre-service teachers' understanding of TPACK. As the authors explained, pre-service teachers likely failed to differentiate between their knowledge of general pedagogies (PK) and their use in teaching particular content areas (PCK). They also interpreted the items of TCK, TPK, and TPACK as being conceptually similar. Following the suggestion of Koh et al. (2010), the third factor was labelled as knowledge of pedagogy (KP) and the fourth factor as knowledge of teaching with technology (KTT). The four factors (TK, CK, KP, and KTT) had 4, 2, 8, and 11 items, respectively, and the alpha reliability of the factors ranged from .861 to .907 . 
Table 2. Results of exploratory factor analysis on the TPACK items

\begin{tabular}{|c|c|c|}
\hline \multirow{2}{*}{\multicolumn{3}{|c|}{ Technology Knowledge (TK, $\alpha=.907)$}} \\
\hline & & \\
\hline TK1. & I know how to solve my own technical problems & .828 \\
\hline TK2. & I can learn technology easily & .856 \\
\hline TK3. & I keep up with important new technologies & .832 \\
\hline TK4. & I have the technical skills I need to use technology & .816 \\
\hline \multicolumn{3}{|c|}{ Content Knowledge (CK, $\alpha=.867)$} \\
\hline CK1. & I have sufficient knowledge about the content I am teaching & .652 \\
\hline CK2. & I have various ways and strategies of developing my understanding of the content I teach & .984 \\
\hline \multicolumn{3}{|c|}{ Knowledge of Pedagogy (KP, $\alpha=.861)$} \\
\hline PK1. & I know how to assess student performance in a classroom & .645 \\
\hline PK2. & I can adapt my teaching based upon what students currently understand or do not understand & .557 \\
\hline PK3. & I can adapt my teaching style to different learners & .700 \\
\hline PK4. & I can assess student learning in multiple ways & .796 \\
\hline PK5. & I can use a wide range of teaching approaches in a classroom setting & .780 \\
\hline PK6. & I am familiar with common student understandings and misconceptions & .438 \\
\hline PK7. & I know how to organize and maintain classroom management & .732 \\
\hline PCK1. & $\begin{array}{l}\text { I can select effective teaching approaches to guide student thinking and learning in the content } \\
\text { areas I teach }\end{array}$ & .526 \\
\hline \multicolumn{3}{|c|}{ Knowledge of Teaching with Technology (KTT, $\alpha=.898$ ) } \\
\hline TCK1. & I know about technologies that I can use for understanding and doing what I teach & .560 \\
\hline TPK1. & I can choose technologies that enhance the teaching approaches for a lesson & .686 \\
\hline TPK2. & I can choose technologies that enhance students' learning for a lesson & .634 \\
\hline$\overline{\text { TPK3. }}$ & $\begin{array}{l}\text { My teacher education program made me think more deeply about how technology could influence } \\
\text { my teaching approaches }\end{array}$ & .591 \\
\hline TPK4. & I am thinking critically about how to use technology in my classroom & .537 \\
\hline TPK5. & I can adapt the use of the technologies that I am learning about to different teaching activities & .893 \\
\hline TPK6. & $\begin{array}{l}\text { I can select technologies to use in my classroom that enhance what I teach, how I teach and what } \\
\text { students learn }\end{array}$ & .844 \\
\hline TPK7. & $\begin{array}{l}\text { I can use strategies that combine content, technologies and teaching approaches that I learned } \\
\text { about in my coursework in my classroom }\end{array}$ & .869 \\
\hline TPK8. & $\begin{array}{l}\text { I can provide leadership in helping others to coordinate the use of content, technologies and } \\
\text { teaching approaches at my school and/or district }\end{array}$ & .513 \\
\hline TPK9. & I can choose technologies that enhance the content for a lesson & .531 \\
\hline TPACK1. & $\begin{array}{l}\text { I can teach lessons that appropriately combine content knowledge, technologies and teaching } \\
\text { approaches }\end{array}$ & .515 \\
\hline
\end{tabular}

Table 3. Descriptive statistics and intercorrelations among the major variables

\begin{tabular}{|c|c|c|c|c|c|c|c|c|c|}
\hline & Mean & SD & 1 & 2 & 3 & 4 & 5 & 6 & 7 \\
\hline 1. Media Sharing (MS) & 5.097 & 1.524 & - & & & & & & \\
\hline 2. Internet Searching (IS) & 6.455 & 1.384 & $.473^{* *}$ & - & & & & & \\
\hline 3. Video Gaming (VG) & 4.411 & 2.128 & $.472^{\star *}$ & $.300^{\star *}$ & - & & & & \\
\hline 4. Technology Knowledge (TK) & 3.494 & .831 & $.237^{\star}$ & .124 & $.204^{* *}$ & - & & & \\
\hline 5. Content Knowledge (CK) & 3.736 & .713 & .008 & -.075 & .049 & $.448^{\star \star}$ & - & & \\
\hline 6. Knowledge of Pedagogy (KP) & 3.608 & .455 & $.277^{\star \star}$ & .091 & $.147^{\star}$ & $.208^{\star \star}$ & $.413^{* *}$ & - & \\
\hline 7. Knowledge of Teaching with Technology (KTT) & 3.620 & .457 & $.302^{* *}$ & .126 & $.145^{*}$ & $.367^{\star \star}$ & $.352^{\star *}$ & $.564^{\star *}$ & - \\
\hline
\end{tabular}

Descriptive statistics and intercorrelations among the SMU and TPACK variables are presented in Table 3. On average, pre-service teachers engaged in MS several times a week, IS once a day, and VG once a week. They were most competent in CK, followed by KTT, KP, and TK. The factors within the SMU and TPACK constructs had significantly positive correlations with each other. MS and VG also had significantly positive associations with TK, $\mathrm{KP}$, and KTT. In particular, it is evident from Table 3 that MS had higher positive correlations with TK, KP, and KTT than VG.

Figure 1 shows the hypothesised path analysis model. The theoretical framework of the study hypothesises that there exist relationships between SMU in informal settings and TPACK among pre-service teachers and yet the relationships between specific components of SMU and TPACK have yet to be determined from the empirical data collected. Therefore, all the possible paths between the components of the two constructs were added. Before the 


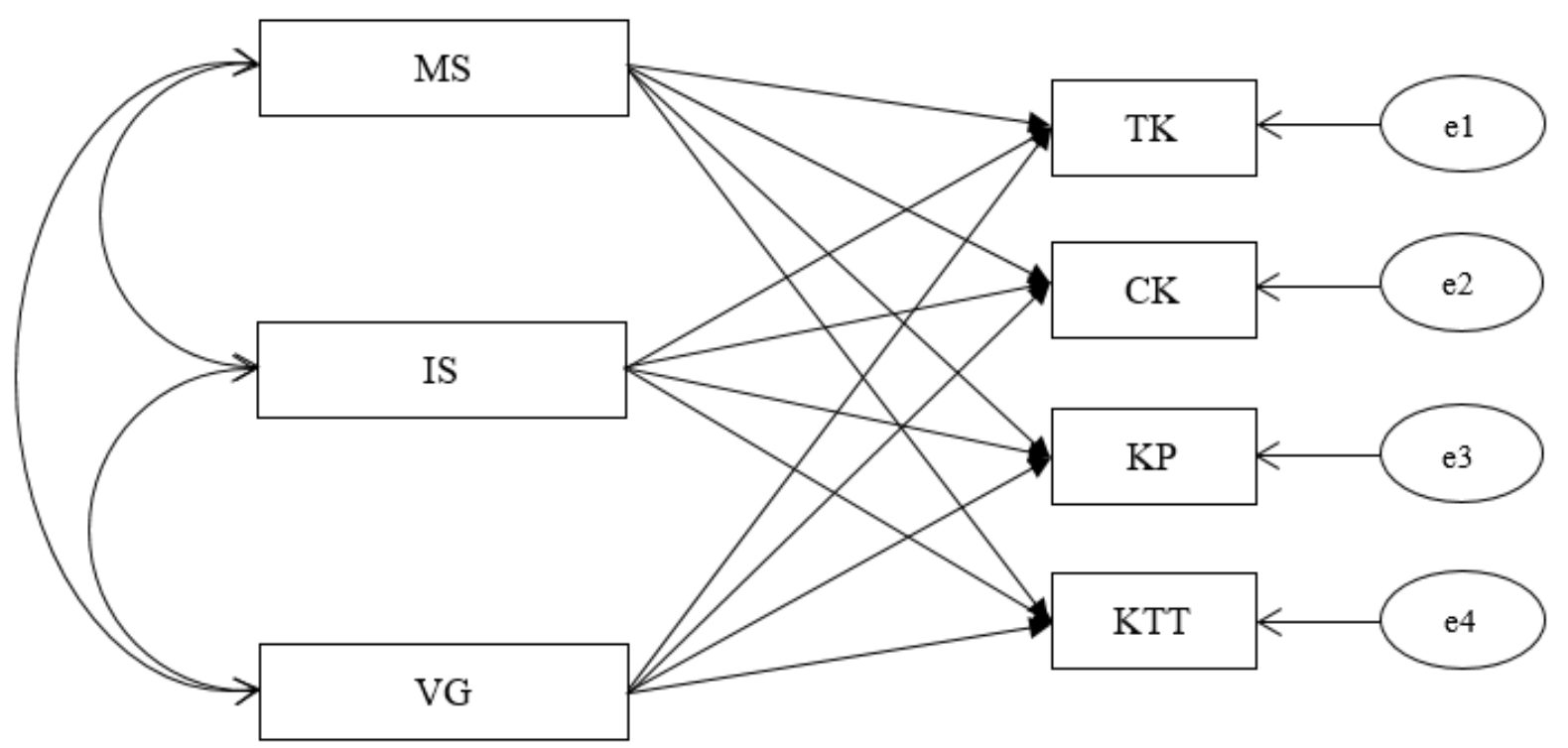

Figure 1. Hypothesised path analysis model showing the relationships between SMU in informal settings and TPACK for preservice teachers

Table 4. Results of the path analysis of the hypothesised model

\begin{tabular}{ccccc}
\hline \multicolumn{5}{c}{ Standardised regression coefficient } \\
\hline MS & TK & CK & KP & KTT \\
\hline IS & $.359^{\star \star *}$ & .164 & .015 & $.376^{\star * *}$ \\
\hline VG & -.026 & .057 & -.080 & -.062 \\
\hline $\boldsymbol{R}^{\mathbf{2}}$ & -.005 & .070 & .029 & -.073 \\
\hline & $.118^{\star *}$ & .060 & .005 & $.101^{*}$ \\
\hline
\end{tabular}

${ }^{*} p<.05 .{ }^{* \star} p<.01 .{ }^{* * \star} p<.001$.

model was tested, the data were checked for the assumptions of the absence of outliers and normality. Univariate outliers exist if the absolute values of the z scores are greater than 3.29 ( $p<.001)$ (In'nami \& Koizumi, 2013). There were only four cases, which was considered to be a negligible result. For multivariate outliers, the Mahalanobis distances of all cases were computed and compared with the critical value of $\chi^{2}(7)=20.278$ at the alpha level of .005 . Seven cases were found to be multivariate outliers and were removed from the data set. Therefore, the sample size was reduced to 205 .

A variable has a univariate normal distribution if the absolute value of the $\mathrm{z}$ scores of its skewness and kurtosis are less than 3.29 ( $\mathrm{p}<$.001) (In'nami \& Koizumi, 2013). The variables MS, TK, and CK failed to fulfil this requirement. As expected, multivariate normality was not tenable because the tests for both multivariate skewness and kurtosis were statistically significant (Wang \& Wang, 2012). In view of the nonnormality of the data, a maximum likelihood estimation method with robust standard errors was chosen to obtain robust estimates of the model parameters.

Table 4 shows the results of the path analysis of the hypothesised model. Only MS exerted significantly positive effects on TK $(\beta=.359, p<.001)$ and KTT $(\beta=.376, p<.001)$. The SMU variables also explained a significant amount of variance in TK $\left(R^{2}=.118, p<.01\right)$ and $\operatorname{KTT}\left(R^{2}=.101, p<.05\right)$.

\section{DISCUSSION}

SMU among university students is pervasive due to the proliferation of various social media tools. Many students use social media in informal settings for various leisure and educational purposes. Although informal learning has been recognised to potentially enhance student learning experiences (Jahnke, 2012), there is a dearth of empirical studies on whether and how SMU in informal settings is related to TPACK for pre-service teachers. This study found that MS was a significantly positive predictor of TK and KTT among pre-service teachers, whereas IS and VG were not predictive of any component of TPACK.

McLoughlin and Lee (2007) discussed the educational affordances of Web 2.0 technologies, such as connectivity and social rapport, collaborative information discovery and sharing, content creation, knowledge and information aggregation, and content modification. These features help explain the present findings. By its nature, MS fosters 
social relationships, collaborative learning, content generation, knowledge creation, and knowledge recreation. Learners become prosumers by simultaneously consuming and producing media resources. However, IS and VG tend to be more consumptive online activities that may not fully illustrate all the aforementioned features of educational affordance. In short, these affordances help learners develop a participatory culture that engenders authentic engagement and communication, and members of online communities forge social connections with one another. Most importantly, the authors argued that the technology-enabled dynamic interactions among ideas, individuals, communities, and information networks are what lead to the coconstruction of knowledge.

In the past, teacher education researchers have mainly focused on using formal ICT courses to prepare preservice teachers to adopt technology in classroom practice (Chai et al., 2012; Chai et al., 2010; Hofer \& Grandgenett, 2012; Horzum, 2013). More recent studies have also included social media tools in the education process (Kumar \& Leeman, 2013; Lemon, 2016; Tur \& Marin, 2015). These courses have successfully developed various components of TPACK for pre-service teachers. However, this study highlighted the fact that SMU in informal settings, in particular MS, is significantly related to TK and KTT among pre-service teachers. This finding extends our conception and practice of technology integration in education for pre-service teachers. Social media appear to play a prominent role in teaching with technology.

The findings of this study also have implications for teacher education. In general, education technology courses for pre-service teachers pay insufficient attention to whether students already possess TPACK (Mouza \& KarchmerKlein, 2015). This study shows that students are likely to have acquired some TPACK beforehand, as predicted by their SMU. Teacher educators may thus elicit this knowledge at the beginning of relevant courses, allowing them to adopt a more personalised approach to pre-service teacher technology professional development.

Despite the potential benefits of SMU for pre-service teacher learning, this study has several limitations that merit further investigation. First, although the items used to measure SMU and TPACK were shown to have desirable psychometric properties, more research is required to understand whether the use of a frame of reference in an item may affect participant responses (Lievens, De Corte, \& Schollaert, 2008). For example, in MS5, the item 'Share your own media files on a computer' can be contextualised as 'Share your own media files on a computer when doing academic work'. Second, the process through which SMU affects pre-service teachers' acquisition of TPACK is worth investigating. Third, future researchers could explore how formal and informal learning that incorporates social media may be integrated to support self-regulated student learning. The three-level pedagogical framework comprising personal information management, social interaction and collaboration, and information aggregation and management can serve as a guiding structure for such investigation (Dabbagh \& Kitsantas, 2012). Finally, like other cross-sectional studies, this study makes no attempt to infer causality between SMU and TPACK among pre-service teachers. Such work should be conducted in future longitudinal research.

\section{CONCLUSION}

Despite being confronted with the reality that SMU among pre-service teachers has soared in recent years, teacher educators may not recognise the educational potential of this trend. The incorporation of SMU into teacher education programmes is intended to deepen teacher educators' understanding of the knowledge and practices required to meet the challenges of training pre-service teachers in an increasingly technology-driven society, as well as how innovation in education technology courses can be made possible through the effective and novel use of social media technologies in universities.

To obtain the educational benefits of SMU, more empirical evidence is required to tease out the nuances involved. This study, a pioneering work in this research area, found that SMU in informal settings is associated with TPACK for pre-service teachers. Specifically, MS is shown to play a crucial role in the prediction of TK and KTT. This study opens up an alternative avenue for researchers and teacher educators alike to rethink theory and practice with regard to preparing pre-service teachers to integrate technology into their professional practices.

\section{ACKNOWLEDGEMENTS}

This work was supported by the Direct Grant for Research (2014-15) under Grant Number 4058030 of the Chinese University of Hong Kong awarded to the author of the paper. My thanks go to all the pre-service teachers for contributing the data for analysis and Joey Hung, Agnes Lee, and Cecilia Yuen for their help in collecting the data. 


\section{REFERENCES}

Alayyar, G. M., Fisser, P., \& Voogt, J. (2012). Developing technological pedagogical content knowledge in preservice science teachers: Support from blended learning. Australasian Journal of Educational Technology, 28(8), 1298-1316. https:// doi.org/10.14742/ajet.773

Bahrani, T., Sim, T. S., \& Nekoueizadeh, M. (2014). Second language acquisition in informal setting. Theory and Practice in Language Studies, 4(8), 1714-1723. https:/ / doi.org/10.4304/tpls.4.8.1714-1723

Barnes, N. G., \& Lescault, A. M. (2011). Social media soars as higher-ed experiments and reevaluates its use of new communications tools. Retrieved from http://sncr.org/sites/default/files/higherEd.pdf

Baruah, T. D. (2012). Effectiveness of social media as a tool of communication and its potential for technology enabled connections: A micro level study. International Journal of Scientific and Research Publications, 2(5), 110.

Bilici, S. C., Guzey, S. S., \& Yamak, H. (2016). Assessing pre-service science teachers' technological pedagogical content knowledge (TPACK) through observations and lesson plans. Research in Science E Technological Education, 34(2), 237-251. https:/ / doi.org/10.1080/02635143.2016.1144050

Carpenter, J. P., \& Krutka, D. G. (2015). Social media in teacher education. In M. L. Niess \& H. Gillow-Wiles (Eds.), Handbook of research on teacher education in the digital age (pp. 28-54). Hershey, PA: IGI Global. https:// doi.org/10.4018/978-1-4666-8403-4.ch002

Chai, C. S., Koh, J. H. L., Ho, H. N. J., \& Tsai, C.-C. (2012). Examining preservice teachers' perceived knowledge of TPACK and cyberwellness through structural equation modeling. Australasian Journal of Educational Technology, 28(6), 1000-1019. https:/ / doi.org/10.14742/ajet.807

Chai, C. S., Koh, J. H. L., \& Tsai, C.-C. (2010). Facilitating preservice teachers' development of technological, pedagogical, and content knowledge (TPACK). Educational Technology E Society, 13(4), 63-73.

Charlesworth, Z. M., \& Sarrasin, N. B. (2014). Pedagogy for a digital age: Barriers and drivers for the co-construction of knowledge in higher education. Proceedings of World Conference on Educational Media and Technology 2014 (pp. 1967-1973). Waynesville, NC: Association for the Advancement of Computing in Education (AACE).

Dabbagh, N., \& Kitsantas, A. (2012). Personal learning environments, social media, and self-regulated learning: A natural formula for connecting formal and informal learning. The Internet and Higher Education, 15(1), 3-8. https:/ / doi.org/10.1016/j.iheduc.2011.06.002

Ertmer, P. A. (1999). Addressing first- and second-order barriers to change: strategies for technology integration. Educational Technology Research and Development, 47(4), 47-61. https:/ / doi.org/10.1007/BF02299597

Ertmer, P. A., Ottenbreit-Leftwich, A. T., Sadik, O., Sendurur, E., \& Sendurur, P. (2012). Teacher beliefs and technology integration practices: A critical relationship. Computers $\mathcal{E}$ Education, 59(2), 423-435. https://doi.org/10.1016/j.compedu.2012.02.001

Gibson, D. (2008). Make it a two-way connection: A response to "Connecting informal and formal learning experiences in the age of participatory media". Contemporary Issues in Technology and Teacher Education, 8(4), 305-309.

Greenhow, C., \& Lewin, C. (2016). Social media and education: Reconceptualizing the boundaries of formal and informal learning. Learning, Media and Technology, 41(1), 6-30. https:/ / doi.org/10.1080/17439884.2015.1064954

Hofer, M., \& Grandgenett, N. (2012). TPACK development in teacher education: A longitudinal study of preservice teachers in a secondary M.A.Ed. program. Journal of Research on Technology in Education, 45(1), 83-106. https: / / doi.org/10.1080/15391523.2012.10782598

Horzum, M. B. (2013). An investigation of the technological pedagogical content knowledge of pre-service teachers. Technology, Pedagogy and Education, 22(3), 303-317. https:/ / doi.org/10.1080/1475939X.2013.795079

$\mathrm{Hu}$, T., \& Zhang, P. (2016). Social media usage as a formative construct: Conceptualization, validation, and implication. Journal of Information Technology Management, 27(4), 151-168.

In'nami, Y., \& Koizumi, R. (2013). Structural equation modeling in educational research: A primer. In M. S. Khine (Ed.), Applications of structural equation modeling in educational research and practice (pp. 23-51). Rotterdam, the Netherlands: Sense Publishers. https://doi.org/10.1007/978-94-6209-332-4_2

Izquierdo, I., Olea, J., \& Abad, F. J. (2014). Exploratory factor analysis in validation studies: Uses and recommendations. Psicothema, 26(3), 395-400.

Jahnke, I. (2012). Informal learning via social media-Preparing for didactical designs. In A. Tokar, M. Beurskens, S. Keuneke, M. Mahrt, I. Peters, C. Puschmann, T. v. Treeck, \& K. Weller (Eds.), Science and the Internet (pp. 5972). Dusseldorf: Dusseldorf University Press. 
Jenkins, H., Purushotma, R., Weigel, M., Clinton, K., \& Robinson, A. J. (2009). Confronting the challenges of participatory culture: Media education for the 21st century. Retrieved from http:/ / mitpress.mit.edu/sites/default/files/titles/free_download/9780262513623_Confronting_the_Chal lenges.pdf

Johnson, L., Adams Becker, S., Estrada, V., \& Freeman, A. (2015). NMC Horizon Report: 2015 Higher Education Edition. Austin, Texas: The New Media Consortium.

Jordan, K. (2013). The influence of gender on beginning teachers' perceptions of their technological pedagogical content knowledge (TPACK). Australian Educational Computing, 28(2), 32-50.

Junco, R. (2012). Too much face and not enough books: The relationship between multiple indices of Facebook use and academic performance. Computers in Human Behavior, 28(1), 187-198. https://doi.org/10.1016/j.chb.2011.08.026

Kaplan, A., \& Haenlein, M. (2010). Users of the world, unite! The challenges and opportunities of social media. Business Horizons, 53(1), 59-68. https:/ / doi.org/10.1016/j.bushor.2009.09.003

Kiedrowski, K. v. L., Mahrholz, N., Griesbaum, J., \& Rittberger, M. (2015). Social media usage in education related web search: An analysis of the information behavior of students of education related study paths in Germany. In F. Pehar, C. Schlögl, \& C. Wolff (Eds.), Proceedings of the 14th International Symposium on Information Science (ISI 2015) (pp. 264-277). Glückstadt: Verlag Werner Hülsbusch.

Koh, J. H. L., Chai, C. S., \& Tsai, C. C. (2010). Examining the technological pedagogical content knowledge of Singapore preservice teachers with a large-scale survey. Journal of Computer Assisted Learning, 26, 563-573. https:/ / doi.org/10.1111/j.1365-2729.2010.00372.x

Koh, J. H. L., \& Divaharan, S. (2011). Developing pre-service teachers' technology integration expertise through the TPACK-developing instructional model. Journal of Educational Computing Research, 44(1), 35-58. https:/ / doi.org/10.2190/EC.44.1.c

Kolb, D. (1984). Experiential learning: Experience as the source of learning and development. Englewood Cliffs: PrenticeHall, Inc.

Korkmaz, U., \& Avci, Z. Y. (2016). Turkish pre-service teachers' experiences with contemporary technology games and perceptions about teaching with instructional games. Research in Social Sciences and Technology, 1(1), 4458.

Kumar, S., \& Leeman, J. (2013). Connecting pre-service teachers and experienced educators: Social media for lifelong learning. International Journal of Technologies in Higher Education, 10(3), 28-41. https:/ / doi.org/10.7202/1035577ar

Lau, W. W. F. (2017). Effects of social media usage and social media multitasking on the academic performance of university students. Computers in Human Behavior, 68, 286-291. https:/ / doi.org/10.1016/j.chb.2016.11.043

Lau, W. W. F., \& Yuen, A. H. K. (2013a). Educational technology training workshops for mathematics teachers: An exploration of perception changes. Australasian Journal of Educational Technology, 29(4), 595-611. https://doi.org/10.14742/ajet.335

Lau, W. W. F., \& Yuen, A. H. K. (2013b). Learning study in mathematics: It is for students, teachers, and teacher educators. The Asia-Pacific Education Researcher, 22(4), 377-388. https:/ / doi.org/10.1007/s40299-012-0034-0

Lemon, N. (2016). Tweeting as a pre-service teacher: Learning to use Twitter for professional use. Retrieved from http:/ / www.fusion-journal.com/tweeting-as-a-pre-service-teacher-learning-to-use-twitter-forprofessional-use/

Lievens, F., De Corte, W., \& Schollaert, E. (2008). A closer look at the frame-of-reference effect in personality scale scores and validity. Journal of Applied Psychology, 93(2), 268-279. https:/ / doi.org/10.1037/0021-9010.93.2.268

Mâță, L. (2014). Social media tools in initial teacher education. In J.-E. Pelet (Ed.), E-learning 2.0 technologies and web applications in higher education (pp. 129-154). Hershey, PA: IGI Global. https:// doi.org/10.4018/978-1-46664876-0.ch007

McLoughlin, C., \& Lee, M. J. W. (2007). Social software and participatory learning: Pedagogical choices with technology affordances in the Web 2.0 era. In R. J. Atkinson, C. McBeath, S. K. A. Soong, \& C. Cheers (Eds.), ICT: Providing choices for learners and learning (pp. 664-675). Centre for Educational Development, Nanyang Technological University, Singapore: ASCILITE.

McLoughlin, C., \& Lee, M. J. W. (2008). The three p's of pedagogy for the networked society: Personalization, participation, and productivity. International Journal of Teaching and Learning in Higher Education, 20(1), 1027. 
Mishra, P., \& Koehler, M. (2006). Technological pedagogical content knowledge: A framework for teacher knowledge. Teachers College Record, 108(6), 1017-1054. https:/ / doi.org/10.1111/j.1467-9620.2006.00684.x

Mouza, C. (2016). Developing and assessing TPACK among pre-service teachers: A synthesis of research. In M. C. Herring, M. J. Koehler, \& P. Mishra (Eds.), Handbook of technological pedagogical content knowledge (TPACK) for educators (2nd ed.) (pp. 169-190). New York, NY: Routledge.

Mouza, C., \& Karchmer-Klein, R. (2015). Designing effective technology preparation opportunities for preservice teachers. In C. Angeli \& N. Valanides (Eds.), Technological pedagogical content knowledge: Exploring, developing, and assessing TPCK (pp. 115-136). New York: Springer. https:/ / doi.org/10.1007/978-1-4899-8080-9_6

Nadelson, L. S., Bennett, S., Gwilliam, E., Howlett, C., Oswalt, S., \& Sand, J. (2013). The intersection of preservice teachers' confidence, perceptions, and ideas for using instructional technology for teaching and learning. International Journal of Higher Education, 2(4), 77-90. https:/ / doi.org/10.5430/ijhe.v2n4p77

Oskay, Ö. Ö. (2017). An investigation of teachers' self efficacy beliefs concerning educational technology standards and technological pedagogical content knowledge. EURASIA Journal of Mathematics, Science and Technology Education, 13(8), 4739-4752. https:/ / doi.org/10.12973/eurasia.2017.00961a

Rosen, L. D., Whaling, K. K., Carrier, L. M., Cheever, N. A., \& Rokkum, J. J. (2013). The media and technology usage and attitudes scale: An empirical investigation. Computers in Human Behavior, 29(6), 2501-2511. https://doi.org/10.1016/j.chb.2013.06.006

Schmidt, D. A., Baran, E., Thompson, A. D., Mishra, P., Koehler, M. J., \& Shin, T. S. (2009). Technological pedagogical content knowledge (TPCK): The development and validation of an assessment instrument for preservice teachers. Journal of Research on Technology in Education, 42(2), 123-149. https:/ / doi.org/10.1080/15391523.2009.10782544

Shulman, L. S. (1987). Knowledge and teaching: Foundations of the new reform. Harvard Educational Review, 57(1), 1-23. https://doi.org/10.17763/haer.57.1.j463w79r56455411

Smith, B. G., \& Gallicano, T. D. (2015). Terms of engagement: Analyzing public engagement with organizations through social media. Computers in Human Behavior, 53, 82-90. https:/ / doi.org/10.1016/j.chb.2015.05.060

Stoicheva, M., Mavrodieva, I., \& Tsvetkova, N. (2012). Social media and social networks - What's in for tertiary education. Retrieved from http://rhetoric.bg/social-media-and-social-networks-whats-in-for-tertiaryeducation

Thompson, A., \& Mishra, P. (2007). Breaking news: TPCK becomes TPACK! . Journal of Computing in Teacher Education, 24(2), 38-64.

Tokmak, H. S. (2015). Pre-service teachers' perceptions on TPACK development after designing educational games. Asia-Pacific Journal of Teacher Education, 43(5), 392-410. https:/ / doi.org/10.1080/1359866X.2014.939611

Tsai, C. C., \& Chai, C. S. (2012). The "third"-order barrier for technology integration instruction: implications for teacher education. Australasian Journal of Educational Technology, 28(6), 1057-1060. https://doi.org/10.14742/ajet.810

Tur, G., \& Marin, V. I. (2015). Enhancing learning with the social media: Student teachers' perceptions on Twitter in a debate activity. New Approaches in Educational Research, 4(1), 46-53. https:// doi.org/10.7821/naer.2015.1.102

Wang, J., \& Wang, X. (2012). Structural equation modeling: Applications using Mplus. New York: John Wiley. https:// doi.org/10.1002/9781118356258

Yong, A. G., \& Pearce, S. (2013). A beginner's guide to factor analysis: Focusing on exploratory factor analysis. Tutorials in Quantitative Methods for Psychology, 9(2), 79-94. https:/ / doi.org/10.20982/tqmp.09.2.p079

\section{http://www.ejmste.com}

